\title{
Front Matter: Volume 8403
}

, "Front Matter: Volume 8403," Proc. SPIE 8403, Modeling and Simulation for Defense Systems and Applications VII, 840301 (14 May 2012); doi: 10.1117/12.977657

SPIE Event: SPIE Defense, Security, and Sensing, 2012, Baltimore, Maryland, United States 


\section{PROCEEDINGS OF SPIE}

\section{Modeling and Simulation for Defense Systems and Applications VII}

Eric J. Kelmelis

Editor

24 April 2012

Baltimore, Maryland, United States

Sponsored and Published by

SPIE

Volume 8403

Proceedings of SPIE, 0277-786X, v. 8403 
The papers included in this volume were part of the technical conference cited on the cover and title page. Papers were selected and subject to review by the editors and conference program committee. Some conference presentations may not be available for publication. The papers published in these proceedings reflect the work and thoughts of the authors and are published herein as submitted. The publisher is not responsible for the validity of the information or for any outcomes resulting from reliance thereon.

Please use the following format to cite material from this book:

Author(s), "Title of Paper," in Modeling and Simulation for Defense Systems and Applications VII, edited by Eric J. Kelmelis, Proceedings of SPIE Vol. 8403 (SPIE, Bellingham, WA, 2012) Article CID Number.

ISSN 0277-786X

ISBN 9780819490810

Published by

SPIE

P.O. Box 10, Bellingham, Washington 98227-0010 USA

Telephone +1 3606763290 (Pacific Time) · Fax +1 3606471445

SPIE.org

Copyright (C) 2012, Society of Photo-Optical Instrumentation Engineers

Copying of material in this book for internal or personal use, or for the internal or personal use of specific clients, beyond the fair use provisions granted by the U.S. Copyright Law is authorized by SPIE subject to payment of copying fees. The Transactional Reporting Service base fee for this volume is $\$ 18.00$ per article (or portion thereof), which should be paid directly to the Copyright Clearance Center (CCC), 222 Rosewood Drive, Danvers, MA 01923. Payment may also be made electronically through CCC Online at copyright.com. Other copying for republication, resale, advertising or promotion, or any form of systematic or multiple reproduction of any material in this book is prohibited except with permission in writing from the publisher. The CCC fee code is 0277-786X/12/\$18.00.

Printed in the United States of America.

Publication of record for individual papers is online in the SPIE Digital Library.

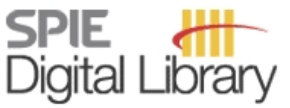

SPIEDigitalLibrary.org

Paper Numbering: Proceedings of SPIE follow an e-First publication model, with papers published first online and then in print and on CD-ROM. Papers are published as they are submitted and meet publication criteria. A unique, consistent, permanent citation identifier (CID) number is assigned to each article at the time of the first publication. Utilization of CIDs allows articles to be fully citable as soon as they are published online, and connects the same identifier to all online, print, and electronic versions of the publication. SPIE uses a six-digit CID article numbering system in which:

- The first four digits correspond to the SPIE volume number.

- The last two digits indicate publication order within the volume using a Base 36 numbering system employing both numerals and letters. These two-number sets start with 00, 01, 02, 03, 04, $05,06,07,08,09,0 A, 0 B \ldots 0 Z$, followed by 10-1Z, 20-2Z, etc.

The CID number appears on each page of the manuscript. The complete citation is used on the first page, and an abbreviated version on subsequent pages. Numbers in the index correspond to the last two digits of the six-digit CID number. 


\section{Contents}

$\checkmark \quad$ Conference Committee

SESSION 1 OPTICAL AND ELECTRONIC SYSTEMS

840303 Optical processors using semiconductor optical amplifiers [8403-02]

S. Ma, W. Li, H. Hu, N. K. Dutta, Univ. of Connecticut (United States)

\section{SESSION 2 IMAGING AND SENSORS}

840305 Infrared imagery acquisition process supporting simulation and real image training [8403-04]

J. O'Connor, U.S. Army Night Vision \& Electronic Sensors Directorate (United States)

840306 Development of radiometrically accurate synthetic thermal infrared video for tracking algorithm evaluation [8403-05]

D. B. Rhodes, Z. Ninkov, Rochester Institute of Technology (United States); J. D. Newman, P. P. K. Lee, G. J. Gosian, ITT Exelis Geospatial Systems (United States)

840307 Software for multimodal battlefield signal modeling and optimal sensor placement [8403-06] K. K. Yamamoto, S. N. Vecherin, D. K. Wilson, U.S. Army Cold Regions Research and Engineering Lab. (United States); C. T. Borden, E. Bettencourt, AER, Inc. (United States);

C. L. Pettit, U.S. Naval Academy (United States)

\section{SESSION 3 HETEROGENEOUS COMPUTING}

840308 Dealing with performance/portability and performance/accuracy trade-offs in heterogeneous computing systems: a case study with matrix multiplication modulo primes [8403-07]

M. Wezowicz, B. D. Saunder, M. Taufer, Univ. of Delaware (United States)

8403 OA ArrayFire: a GPU acceleration platform [8403-09]

J. Malcolm, P. Yalamanchili, C. McClanahan, V. Venugopalakrishnan, K. Patel,

J. Melonakos, AccelerEyes (United States)

\section{SESSION 4 COMPLEX SYSTEMS}

8403 OD Analysis of Special Nuclear Material (SNM) detection and interdiction using a collaborative constructive simulation environment [8403-12]

L. A. Hendrix, J. Calman, B. M. Fisher, S. W. Kay, C. M. Lavelle, R. M. Mayo, B. E. Miller,

K. M. Ruben, R. L. West, Johns Hopkins Univ. Applied Physics Lab. (United States) 
8403 OF Data models as a general fast framework for converting simulations at all scales into fast real-time approximations [8403-14]

H. Jaenisch, Johns Hopkins Univ. (United States) and Licht Strahl Engineering INC (United States); J. Handley, Licht Strahl Engineering INC (United States)

8403 OG Methodology for designing M\&S that integrates V\&V processes and documentation [8403-15]

J. N. Elele, N. Gould, Naval Air Systems Command (United States)

\section{SESSION 5 BATTLESPACE AND OPERATIONS}

$8403 \mathrm{OH}$ An analytical approach to air defense: cost, effectiveness and SWOT analysis of employing fighter aircraft and modern SAM systems [8403-16]

O. Kus, I. Kocaman, Y. Topcu, V. Karaca, Turkish Air Force War College (Turkey)

8403 ol Software as a service approach to sensor simulation software deployment [8403-17]

S. Webster, KINEX Inc. (United States); G. Miller, Oakwood Controls Corp. (United States);

G. Mayott, U.S. Army Night Vision \& Electronic Sensors Directorate (United States)

$84030 \mathrm{~J}$ Enhancing army analysis capability for warfighter protection: TRADOC-RDECOM M\&S decision support environment collaboration [8403-18]

K. Athmer, Maneuver Support Ctr. of Excellence (United States); C. Gaughan, U.S. Army Research Lab. (United States); J. S. McDonnell, R. Leach, B. Davis, Dynamic Animation Systems, Inc. (United States); K. Truong, Effective Applications Corp. (United States); H. Borum, R. Leslie, Raytheon Command and Simulations Solutions (United States); L. Ma, Kinex Inc. (United States)

\section{POSTER SESSION}

8403 OK COMBAT: mobile-Cloud-based cOmpute/coMmunications infrastructure for BATtlefield applications [8403-20]

T. Soyata, R. Muraleedharan, J. Langdon, C. Funai, S. Ames, Univ. of Rochester (United States); M. Kwon, Rochester Institute of Technology (United States); W. Heinzelman, Univ. of Rochester (United States)

Author Index 


\title{
Conference Committee
}

\author{
Symposium Chair \\ Kevin P. Meiners, Office of the Secretary of Defense (United States) \\ Symposium Cochair
}

Kenneth R. Israel, Lockheed Martin Corporation (United States)

Conference Chair

Eric J. Kelmelis, EM Photonics, Inc. (United States)

Program Committee

James N. Elele, Naval Air Systems Command (United States)

Susan Harkrider, U.S. Army Night Vision \& Electronic Sensors Directorate (United States)

David J. Thornley, Imperial College London (United Kingdom)

Session Chairs

1 Optical and Electronic Systems

Eric J. Kelmelis, EM Photonics, Inc. (United States)

2 Imaging and Sensors

Ahmed Sharkawy, Lumilant Inc. (United States)

3 Heterogeneous Computing

Daniel Hertenstein, EM Photonics, Inc. (United States)

4 Complex Systems

Keith Athmer, U.S. Army Training and Doctrine Command (United States)

5 Battlespace and Operations

Daniel Mackrides, Phase Sensitive Innovations, Inc. (United States) 
Downloaded From: https://www.spiedigitallibrary.org/conference-proceedings-of-spie on 26 Apr 2023

Terms of Use: https://www.spiedigitallibrary.org/terms-of-use 